\title{
Exclusive bed for thrombolysis. A simple measure that allows $85 \%$ of ischemic stroke patients to be treated in the first hour
}

\author{
Leito exclusivo para trombólise. Uma medida simples que permite que $85 \%$ dos pacientes \\ com acidente vascular cerebral sejam tratados na primeira hora \\ Gabriella Tansini, Renata Dal-Prá Ducci, Edison Matos Nóvak, Francisco Manoel Branco Germiniani, \\ Viviane Flumignan Zétola, Marcos Christiano Lange
}

\begin{abstract}
The door-to-needle time is an important goal to reduce the time to treatment in intravenous thrombolysis. Objective: Analyze if the inclusion of an exclusive thrombolytic bed reduces the door-to-needle time. Method: One hundred and fifty patients admitted for neurological evaluation with ischemic stroke were separated in two groups: in the first, patients were admitted in the Emergency Room for intravenous thrombolysis (ER Group); in the second, patients were admitted in an exclusive thrombolytic bed in the general neurology ward (TB Group). Results: Sixty-eight (86.0\%) patients from TB Group were treated in the first 60 minutes of arrival as compared to 48 (67.6\%) in the ER Group $(p=0.011)$. Conclusion: The introduction of a thrombolytic bed in a general hospital setting can markedly reduce the door-to-needle time, allowing more than $85 \%$ of patients to be treated within the first hour of admission.
\end{abstract}

Keywords: neurology; stroke; treatment; thrombolytic therapy.

RESUMO

A redução no tempo porta-agulha é um objetivo importante para diminuir o tempo de tratamento na trombólise endovenosa. Objetivo: Analisar se a inclusão de um leito exclusivo de trombólise reduz o tempo porta-agulha. Método: Cento e cinqüenta pacientes admitidos com acidente vascular cerebral isquêmico foram separados em dois grupos: no primeiro, os pacientes foram admitidos no Pronto-Atendimento para trombólise endovenosa (Grupo PA); no segundo, os pacientes foram admitidos no leito de trombólise na enfermaria de neurologia (Grupo LT). Resultados: Sessenta e oito (86,0\%) pacientes do Grupo LT foram tratados nos primeiros 60 minutos após a chegada, em comparação com 48 (67,6\%) no Grupo PA ( $p=0,011)$. Conclusão: A introdução de um leito de trombólise em ambiente hospitalar pode reduzir marcadamente o tempo porta-agulha, permitindo que mais de $85 \%$ dos pacientes sejam tratados na primeira hora de admissão.

Palavras-chave: neurologia; acidente vascular cerebral; tratamento; terapia trombolítica.

The outcome of patients submitted to intravenous thrombolysis (IVT) is directly related to the onset-to-needle time and one of the most important goals to reduce the time to treatment is a short door-to-needle time (DNT) ${ }^{1}$. Current guidelines suggest that DNT should be lower than 60 minutes, but only $26 \%$ of patients achieve this goal ${ }^{2}$.

The implementation of simple measures allowed more patients to be treated within the first hour after admission ${ }^{3,45}$. The aim of this study was to analyze whether the inclusion of an exclusive thrombolytic bed (TB) could reduce DNT in a general hospital.

\section{METHOD}

This was an interventional analysis study in which patients evaluated in the first period (pre-intervention; i.e. prior to the implementation of the TB) were compared with the post-intervention group and were used as historical controls. The study subjects were patients admitted with ischemic stroke who were submitted to IVT within 4.5 hours after onset of symptoms between November 2010 and June 2013. There was no formal calculation on the number of patients needed to include in the study, as the structural and

Universidade Federal do Paraná, Departamento de Medicina Interna, Serviço de Neurologia, Curitiba PR, Brazil.

Correspondence: Gabriella Tansini; Hospital de Clínicas, Serviço de Neurologia; Rua General Carneiro, 181 / 4º andar; 80060 -900 Curitiba PR, Brasil; E-mail: gabe.tansini@gmail.com

Conflict of interest: There is no conflict of interest to declare.

Received 17 August 2015; Received in final form 06 November 2015; Accepted 09 December 2015. 
flow measures evaluated were implemented as an improvement strategy mutually agreed by both our service and the Hospital's Directive Board. All data was collected by the same neurologist and fed into our stroke database. This study was authorized by the local hospital ethics committee.

All patients were brought to the hospital by an emergency medical service (EMS). Exclusion criteria for this study were: 1) stroke onset inside the hospital; 2) a diagnosis other than ischemic stroke upon admission; 3) patients with incomplete data in the data bank.

\section{Patient's admission}

Through all the study period, pre-hospital evaluation was similar to a previous published protocol ${ }^{3}$. Briefly, the suspected stroke patient was evaluated by the EMS staff using a standardized checklist based on the Los Angeles Pre-hospital Stroke Screen and Thrombolysis criteria, which were based on current Brazilian guidelines ${ }^{6}$. After completing this checklist, EMS personnel contacted the in-hospital neurologist and took the patient directly to the hospital's CT scan room, where the neurologist, laboratory staff, and CT scan technicians were already awaiting. A brain CT scan was obtained following a concise clinical and neurological examination by a neurologist certified in the National Institutes of Health Stroke Scale (NIHSS) examination, and eligibility to thrombolysis in both groups was individually determined based on the inclusion and exclusion criteria described in the NINDS study, ECASS III and current guidelines ${ }^{6,7,8,9}$.

\section{In-hospital patient's flow}

In the first period (between November 2010 and June 2012), all patients with suspected ischemic stroke, after arrival in the CT room, were admitted to the general Emergency Room (ER), where they were evaluated by the ER team, a neurologist and monitored before IVT - these patients were included in the ER Group.

After July $1^{\text {st }}$ 2012, an exclusive bed for thrombolysis was implemented in the general neurology ward and it was dubbed "Thrombolysis Bed" (TB). Thus, following brain imaging and neurological evaluation, patients were directly sent to the TB, where they were evaluated by the neurology staff, these patients were included in the TB Group. The TB remained vacant at all times, so that patients could be admitted to this exclusive bed for the next 6 hours if they had been treated with IVT. After 6 hours, the patient was relocated to one of the beds available in the neurological ward.

All other measures to the patient management remained the same following the introduction of the TB, except that patients would undergo thrombolysis in this dedicated room. No significant behavioral or structural measures had been taken that could have markedly improved either the time to IVT or the end results of treatment, including the EMS team, number of ambulances, distance from the place of stroke onset and the hospital, number of patients in the
ER, time of arrival to the hospital, time to CT, preparation of rTPa for administration and the staff attending those patients. These analyses were similar to a previously reported study ${ }^{3}$. Throughout the study's period, neurologists were responsible for coordinating the teams and similar measures compared to those done by previous studies were done during all the study period ${ }^{4,5,10}$.

During the study period, a total of 150 ischemic stroke patients were admitted following EMS evaluation and were submitted to IVT; 71 (47.3\%) were admitted in the first period of the study and composed the ER Group, whereas the other $79(52.7 \%)$ were admitted in the second part of the study and composed the TB Group.

\section{Variables}

During the study period, median time and the $1^{\text {st }}$ and $3^{\text {rd }}$ quartiles [Md(1Q-3Q)] from patient's arrival at the hospital and medication infusion (DNT), were analyzed for both groups. Additionally, results from two subsets of patients treated in the first 60 minutes and in the first 40 minutes after hospital's arrival were evaluated.

Statistical analyses were performed with the Statistica 8.0 software: statistical significance was assessed by the MannWhitney's test for continuous variables, and the $\chi 2$-test was used for evaluating the homogeneity of the DNT variable. Statistical significance was set at a $\mathrm{p}<0.05$ value with a 0.95 confidence interval.

\section{RESULTS}

When analyzing the DNT, patients from the Group ER had longer times when compared to the TB Group [45(31.5-61) min vs. 37(26-49.5) min, $\mathrm{p}=0.008)$. In addition, 68 (86.0\%) patients from the TB Group were treated within the first 60 minutes after arrival, as compared to only 48 (67.6\%) of the ER Group $(\mathrm{p}=0.011)$. This was similar for patients treated in the first 40 minutes, $[\mathrm{TB}=42(53.2 \%)$ vs. $\mathrm{ER}=25(35.2 \%), \mathrm{p}=0.033$ ].

\section{DISCUSSION}

The present study demonstrates that the introduction of an exclusive TB in a general hospital can significantly reduce the DNT to thrombolysis in ischemic stroke patients in almost 8 minutes, allowing more than $85 \%$ of patients to be treated in the first hour after arrival, and more than $50 \%$ to be treated in less than 40 minutes from admission.

The relation between reduction in time to treatment and better outcomes had been previously demonstrated in other diseases as myocardial infarction, trauma and sepsis ${ }^{11,12,13,14}$. In the last decade this was also considered in stroke, but only $26 \%$ of patients have the opportunity to receive IVT in the first hour after arrival ${ }^{2}$. 
Previous studies have shown that the treatment performed by neurology experts and the implementation of simple measures reduced the $\mathrm{DNT}^{4,5,10,15}$. In the current study, not only we were able to implement similar measures throughout the study's period, but we also provided patients admitted in the TB group with an additional simple measure, an exclusive bed for IVT treatment. These measures probably were directly related to this significant improvement in DNT observed in the TB Group. In the Helsinki model, the authors had suggested that the direct transport from ambulance stretchers onto the CT table, the stroke team and previously prepared drug infusion already available upon patient's arrival to the CT room seem to be even more crucial for reducing the $\mathrm{DNT}^{4}$.

There are some limitations to this study, including a small number of patients from a single thrombolysis center including only patients submitted to thrombolysis in the first 4.5 hours admitted from the EMS. This was an intervention study with historic controls and a learning curve process may have influence in the reduction of DNT. In comparison with the Helsinki measures ${ }^{4}$, in the present study, we were unable to perform only four measures: 1) premixing of tPA and 2) delivery of tPA on CT table were not available in the hospital because there is only one CT room available for all patients and this could delay the investigation of other patients (also, tPA is not allowed to be administered in the CT room in our hospital); 3) in Brazil there are no unified statewide electronic patient records that could be accessed before admission; and 4) point-of-care INR is not disposable in the public hospital setting.

The current study demonstrated that it is possible to reduce the DNT to IVT with the implementation of few and simple measures in a general hospital, starting before the patient's admission. The introduction of a TB in a general hospital allows more than $85 \%$ of patients to be treated within the first hour of admission.

\section{References}

1. Meretoja A, Keshtkaran M, Saver JL, Tatlisumak T, Parsons MW, Kaste $M$ et al.. Stroke thrombolysis: save a minute, save a day. Stroke. 2014;45(4):1053-8. doi:10.1161/STROKEAHA.113.002910

2. Fonarow GC, Smith EE, Saver JL, Reeves MJ, Bhatt DL, Grau-Sepulveda MV et al. Timeliness of tissue-type plasminogen activator therapy in acute ischemic stroke: patient characteristics, hospital factors, and outcomes associated with door-to-needle times within 60 minutes. Circulation. 2011;123(7):750-8. doi:10.1161/CIRCULATIONAHA.110.974675

3. Lange MC, Zétola VF, Parolin MF, Zamproni LN, Fernandes AF, Piovesan EJ et al. Curitiba acute ischemic stroke protocol: a university hospital and EMS initiative in a large Brazilian city. Arq Neuropsiquiatr. 2011;69(3):441-5. doi:10.1590/S0004-282X2011000400006

4. Meretoja A, Strbian D, Mustanoja S, Tatlisumak T, Lindsberg PJ, Kaste M. Reducing in-hospital delay to 20 minutes in stroke thrombolysis. Neurology. 2012;79(4):306-13. doi:10.1212/WNL.0b013e31825d6011

5. Meretoja A, Weir L, Ugalde M, Yassi N, Yan B, Hand P et al. Helsinki model cut stroke thrombolysis delays to 25 minutes in Melbourne in only 4 months. Neurology. 2013;81(12):1071-6. doi:10.1212/WNL.0b013e3182a4a4d2

6. Martins SC, Freitas GR, Pontes-Neto OM, Pieri A, Moro CH, Jesus PA et al. Guidelines for acute ischemic stroke treatment. Part II: stroke treatment. Arq Neuropsiquiatr. 2012;70(11):885-93. doi:10.1590/S0004-282X2012001100012

7. The National Institute of Neurological Disorders and Stroke rt-PA Stroke Study Group. Tissue plasminogen activator for acute ischemic stroke. N Engl J Med. 1995;333(24):1581-7. doi:10.1056/NEJM199512143332401

8. Jauch EC, Saver JL, Adams HP Jr, Bruno A, Connors JJ, Demaerschalk BM et al. Guidelines for the early management of patients with acute ischemic stroke: a guideline for healthcare professionals from the
American Heart Association/American Stroke Association. Stroke. 2013;44(3):870-947. doi:10.1161/STR.0b013e318284056a

9. Hacke W, Kaste M, Bluhmki E, Brozman M, Dávalos A, Guidetti $D$ et al. Thrombolysis with alteplase 3 to 4.5 hours after acute ischemic stroke. N Engl J Med. 2008;359(13):1317-29. doi:10.1056/NEJMoa0804656

10. Fonarow GC, Zhao X, Smith EE, Saver JL, Reeves MJ, Bhatt DL et al. Door-to-needle times for tissue plasminogen activator administration and clinical outcomes in acute ischemic stroke before and after a quality improvement initiative. JAMA. 2014;311(16):1632-40. doi:10.1001/jama.2014.3203

11. Learmonth SR, Ireland A, McKiernan CJ, Burton P. Does initiation of an ambulance pre-alert call reduce the door to needle time in acute myocardial infarct? Emerg Med J. 2006;23(1):79-81. doi:10.1136/emj.2004.022376

12. Larosa JA, Ahmad N, Feinberg M, Shah M, Dibrienza R, Studer S. The use of an early alert system to improve compliance with sepsis bundles and to assess impact on mortality. Crit Care Res Pract. 2012;2012:980369.

13. Tien HC, Jung V, Pinto R, Mainprize T, Scales DC, Rizoli SB. Reducing time-to-treatment decreases mortality of trauma patients with acute subdural hematoma. Ann Surg. 2011;253(6):1178-83. doi:10.1155/2012/980369

14. Bhakta A, Bloom M, Warren H, Shah N, Casas T, Ewing $T$ et al. The impact of implementing a $24 / 7$ open trauma bed protocol in the surgical intensive care unit on throughput and outcomes. J Trauma Acute Care Surg. 2013;75(1):97-101. doi:10.1097/TA.0b013e31829849e5

15. Fernandes PT, Avelar WM, Mory SB, Hansen R, Li LM. Perception and attitude towards stroke by professionals of emergency medical service in an urban city in southeastern Brazil. J Stroke Cerebrovasc Dis. 2009;18(3):195-7. doi:10.1016/j.jstrokecerebrovasdis.2008.09.007 